\title{
Physicochemical Characterization of Coal Tar Produced by Pyrolysis of Coal from Garin Maiganga and Shankodi Deposits
}

\author{
Sori Ronald Makan', Jock Asanja Alexander ${ }^{2}$, Ryemshak Akila Solomon', \\ Ambayin Nuhu Manasseh' ${ }^{1}$, Ishaku Emmanuel Mbaya' ${ }^{1}$ Putshaka Danladi Julius ${ }^{3}$ \\ ${ }^{1}$ National Metallurgical Development Center, Jos, Nigeria \\ ${ }^{2}$ University of Jos, Jos, Nigeria \\ ${ }^{3}$ Nigerian Institute of Leather and Science Technology, Zaria, Nigeria \\ Email: ^alsanja@gmail.com
}

How to cite this paper: Makan, S.R., Alexander, J.A., Solomon, R.A., Manasseh, A.N., Mbaya, I.E. and Julius, P.D. (2017) Physicochemical Characterization of Coal Tar Produced by Pyrolysis of Coal from Garin Maiganga and Shankodi Deposits. Journal of Minerals and Materials Characterization and Engineering, 5, 288-297. https://doi.org/10.4236/jmmce.2017.55024

Received: May 18, 2017

Accepted: September 8, 2017

Published: September 11, 2017

Copyright $\odot 2017$ by authors and Scientific Research Publishing Inc. This work is licensed under the Creative Commons Attribution International License (CC BY 4.0).

http://creativecommons.org/licenses/by/4.0/

\section{(c) (i) Open Access}

\begin{abstract}
Coal tar was extracted from Garin Maiganga and Shankodi coals by fixed bed pyrolysis process carried out between $325^{\circ} \mathrm{C}$ and $600^{\circ} \mathrm{C}$ at heating rate of $10^{\circ} \mathrm{C} / \mathrm{min}$ and holding time of $30 \mathrm{~min}$. The tar yield determined was $31.95 \%$ for Shankodi and $17.02 \%$ Garin Maiganga. The obtained coal tar samples have the viscosity of 17.5 and $18.0 \mathrm{cP}$ while the density was 0.9119 and 0.9156 $\mathrm{g} / \mathrm{cm}^{3}$ for Garin Maiganga and Shankodi respectively. The solubility of all the coal samples in solvents such as water, benzene, alcohols, acetone, ether and chloroform is similar to the standard tar. The Gas Chromatography-Mass Spectroscopy (GC-MS) was used to analyse the coal tar components. The analysis result showed that the coal tar contained over 48 chemical compounds for Garin Maiganga and over 50 compounds for Shankodi. Benzo and naphthalene compounds were present in all the coal tar samples and these chemicals have wide industrial application.
\end{abstract}

\section{Keywords}

Coal, Pyrolysis, Garin Maiganga and Shankodi

\section{Introduction}

Coal is one of the most abundant fossil fuels. It can be used not only as a source of energy, but as a high-value added raw material for chemicals and carbon based materials. Globally, coal is one of the leading commodities in terms of industrial importance and monetary value [1] [2]. The colour of coal varies from 
light brownish to charcoal black [3]. Coals vary in rank, composition, appearance and type, therefore, the characterization of coal and its products is very important so as to make the most appropriate use of the material [4].

When coal is burnt or carbonized, light gases and tar are released in the form of volatiles. Tars are generally those volatiles that condense to form semi-solid or liquid at room temperature. This initial stage of combustion in which the tar and light gases are released out of the coal is known as pyrolysis, carbonization or devolatilization [5]. Coal pyrolysis is one of the significant approaches for the comprehensive utilization of coal, and one important product of the process is coal tar [6]. Coal tar is one of the by-products of coal carbonization during coke making or coal gasification. Coal tar is a black or brown liquid of extremely high viscosity; it is a complex and variable mixtures of phenols, polycyclic aromatic hydrocarbons (PAHs) and heterocyclic compounds [7]. Coal tar contains approximately 10,000 chemicals of which only about $50 \%$ have been identified [8]. Coal tar contains chemical compounds, which are very valuable. These are aromatic compounds (benzene, toluene, xylene, naphthalene, anthracene, etc.), phenolic compounds (phenol, cresol, xylenol, cathecol, resorcinol, etc.), heterocyclic nitrogen compounds (pyridine, quinolone, isoquinoline, indole, etc.), and oxygen heterocyclic compounds [9]. The composition of coal tar varies with its origin and type of coal (for example lignite, bituminous coal, or anthracite) used in its production [10].

Coal tar has been utilized as raw materials for various industries such as synthetic fibre, medicines, coatings and national defence [6]. It is a type of raw materials from which phenols, naphthalene, anthracene can be extracted for the production of washing oil, cementitious agents, antiseptic agents and catalyst for catalytic hydrogenation to produce gasoline, diesel oil etc. [6]. Coal tar can also be used for the production of soap, ointment and medicated shampoo which is used in the treatment for dandruff and psoriasis, as well as being used to kill and repel head lice [11]. Coal tar is widely used as raw material for insecticides, dyes, medicines, perfumes, colouring matters, and many others.

Coal is playing a fundamental role in global development. Therefore, it must meet a number of economic, social and environmental challenges to demonstrate its role in sustainable development [12]. The utilization of coal tar is fundamentally based on its physicochemical properties, so it is necessary to determine these prior to its end application [13].

This research work therefore is focused on physicochemical analysis of coal tar samples extracted by pyrolysis from Garin Maiganga and Shankodi coal deposits considering the availability of coal in Nigeria.

\section{Methods}

\subsection{Sample Collection and Preparation}

The coal samples used in this research were obtained from two different locations along the Benue trough namely, Garin Maiganga and Shankodi. Garin 
Maiganga coal deposit is located in Akko Local Government Area of Gombe State North-Eastern Nigeria while Shankodi is located in Awe Local Government Area of Nassarawa State, North Central Nigeria as shown in Figure 1.

Samples were randomly collected from different locations in each of the coal deposits at Garin Maiganga, and Shankodi. Bulk samples from each deposit were sized and subjected to coning and quartering. The coal samples underwent further preparation as drying and size reduction. The sample fraction obtained was pulverized with mortar and pestle, until it passed through 250 micron sieve size (used prior to tar extraction). This particle size was chosen in order to produce optimum reaction surface area as well as ease of reproduction of the samples.

\subsection{Coal tar Extraction}

Coal tar extraction was carried out by pyrolysis using a fixed bed pyrolysis operated at a medium temperature under vacuum. The feedstock (coal), heated in a reactor in the absence of air, partly vaporizes and condenses to form a mixture of dark brown liquid (tar), water, gases and the other part residue (char) as shown in Figure 2.

The coal samples weighing $100 \mathrm{~g}$ were placed inside a pyrolysis reactor (500 $\mathrm{ml}$, round bottom flask) each at a time. The reactor containing the coal sample was transferred into the furnace at a set temperature of $325^{\circ} \mathrm{C}$. The furnace

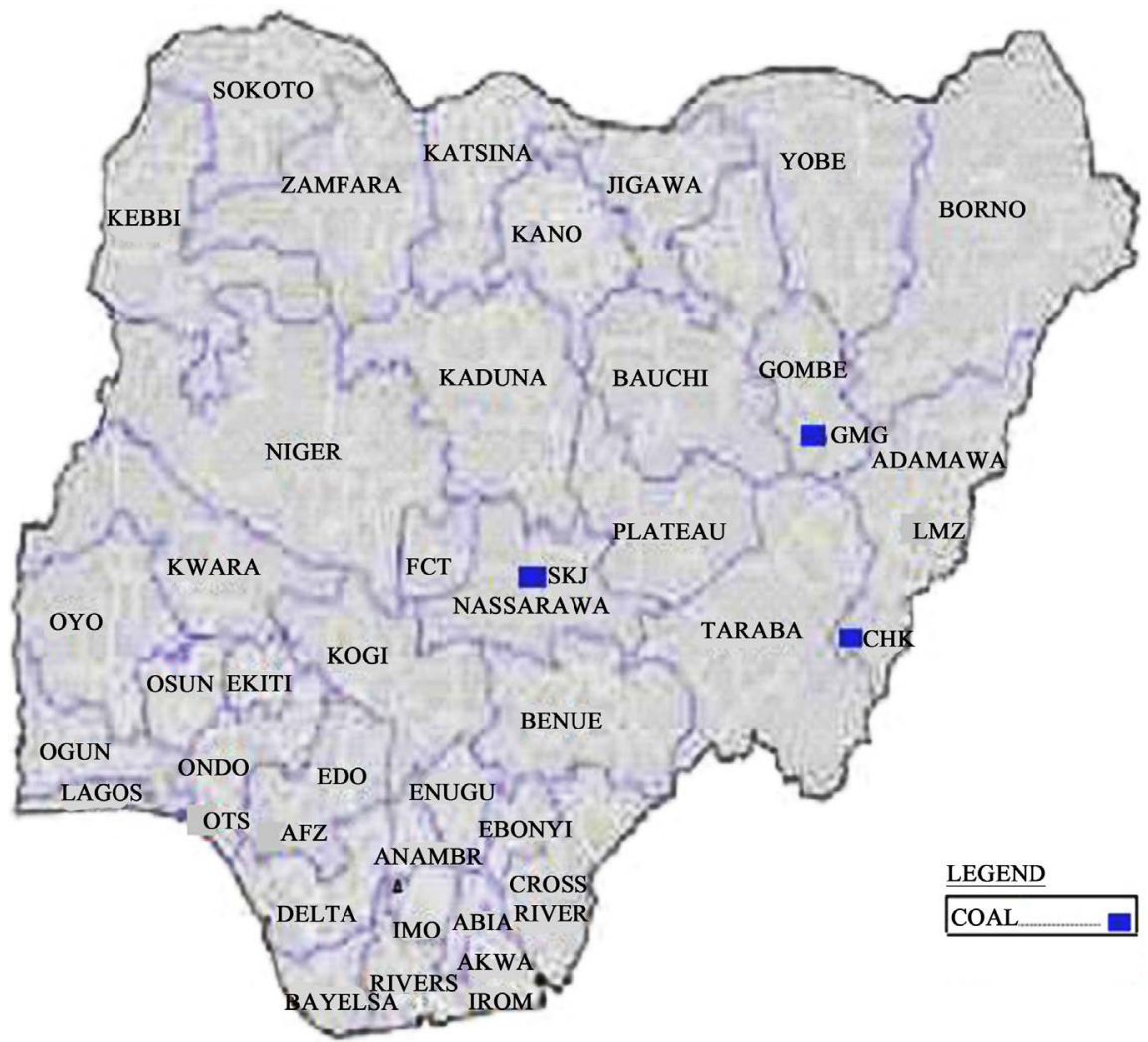

Figure 1. Nigerian map showing coal deposits of Garin Maiganga, Shankodi and Chikila. Source: [14]. 


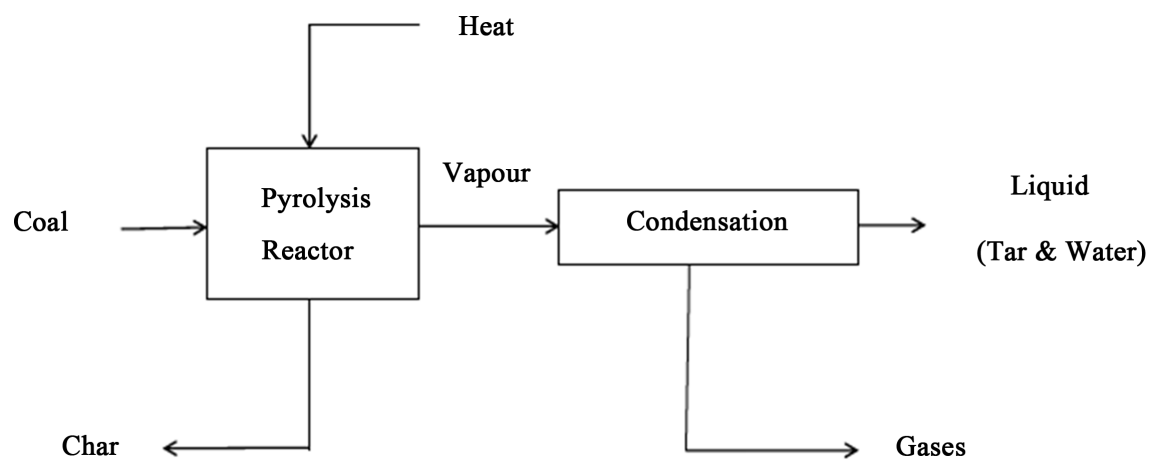

Figure 2. Schematic diagram of material flow of a fixed bed pyrolysis process.

temperature was gradually raised at a rate of $10^{\circ} \mathrm{C}$ per minute up to $600^{\circ} \mathrm{C}$ which was maintained for 30 minutes. The tar alongside with water was collected via a Liebig condenser into $250 \mathrm{~mL}$ beaker (collector). The tar and the water were separated by filtration, using filter paper number 42 . The tar on the filter paper was scooped into a $100 \mathrm{~mL}$ beaker and heated on a hotplate to drive out the remaining water in the tar. The tar was then stored in a sample bottle, wrapped with foil paper and kept in refrigerator, to be used for physical and chemical analysis.

\subsection{Physicochemical Analysis of Coal Tar}

\subsubsection{Coal tar Yield}

The method used for the determination of tar yield was a modification of the one adopted by [15]. The $\%$ coke and tar yields were calculated as follows:

$$
\begin{gathered}
\% \text { coke yield }=\frac{a}{W_{s}} \times 100 \\
\% \text { tar yield }=\frac{b}{W_{s}} \times 100
\end{gathered}
$$

where, $a=$ weight of semi coke residue in the test tube, $b=$ weight of tar and water collected and $W_{s}=$ weight of sample.

Note: The mixture of tar and water $(b)$ was heated to $110^{\circ} \mathrm{C}$ to remove water and other volatile compounds.

\subsubsection{Chemical Composition of Coal Tar}

Chemical composition of the coal tar samples was determined using GCMS-QP2010 SHIMADZU JAPAN. GC/MS is a combination of two different analytical techniques, Gas Chromatography (GC) and Mass Spectrometry (MS), is used to analyse complex organic and biochemical mixtures. GC separates volatile and semi volatile compounds with great resolution while MS provides detailed structural information on most compounds such that they can be exactly identified and quantified. Samples were introduced using calibrated micro syringes into the column (Quartz capillary column) through a heated sample port, injection temperature was $325^{\circ} \mathrm{C}$ and different components of the sample 
are separated. After being separated, the sample was run through a detector, which ionizes the sample and separates the ions and molecular fragments on the basis of their mass-to-charge ratio, collecting and analysing them. Data based on their mass-to-charge ratio and analyzed. Data for the GC-MS was displayed in a total-ion chromatogram, which sums the total ion abundances in each spectrum and plots them as a function of time. The identification comes from the mass spectrum collected at a particular time $(15-20 \mathrm{~min})$ in the chromatogram to recognize the particular component that was eluted at that time.

\subsubsection{Coal tar Viscosity}

The tar viscosity test was carried out by ASTM D166 method. The viscosity of the samples was determined using the Brookfield dial viscometer (Model DV-1, LVT). The sample was placed in a small sample adapter, and then transferred into the sample cup of the viscometer. The viscometer was set at different spindle speed from 0.3 to $100 \mathrm{rpm}$. The viscosity of the tar was measured using spindle T95 at constant temperature $\left(45^{\circ} \mathrm{C}\right)$. The viscosity of the sample was measured and recorded directly in $\mathrm{cP}$.

\subsubsection{Coal tar Density}

The coal tar density was determined using ASTM D70. $24 \mathrm{~mL}$ capacity density bottle was washed, rinsed with water then with ethanol. The bottle was dried in a hot air oven and cooled in a desiccator and weighed. The tar sample heated at $40^{\circ} \mathrm{C}$ was transferred into the empty bottle filled to the neck and tightly closed with the stopper, and the bottle was allowed to cool down to room temperature and weighed. The test was carried out at a temperature of $25^{\circ} \mathrm{C}$ and the density was calculated using as follows:

$$
\text { Density }=\frac{w_{2}-w_{1}}{V}
$$

where $w_{2}=$ weight of bottle filled tar

$w_{1}=$ weight of empty bottle

$V=$ volume of $\operatorname{tar}$ in the bottle.

\subsubsection{Determination of Coal Tar Solubility}

The coal tar solubility test was carried using the method prescribed by ASTM-E1148. The solubility of the tar samples was determined by dissolving it in acetone, benzene, chloroform, ethanol, ether and water.

\subsubsection{Measurement of Tar $\mathrm{pH}$}

The coal tar $\mathrm{pH}$ was measured using digital $\mathrm{pH}$ meter (model $250 \mathrm{pH}$ ) as prescribed by [16]. The $\mathrm{pH}$ of the tar sample was measured at room temperature, $25^{\circ} \mathrm{C}$.

\subsubsection{Refractive Index of Tar Sample}

The refractive index of the tar sample was measured at $25^{\circ} \mathrm{C}$ and recorded with Abbe refractometer according to standard method [17]. 


\section{Results and Discussions}

\subsection{Appearance and Odour of Coal Tar Samples}

The colour of the coal tar extracted from Garin Maiganga and Shankodi were both dark brown and all having a sharp aromatic smell as shown in Table 1. The dark brown colour and aromatic smell of the coal tar samples are similar for standard coal tar [18].

\subsection{Coal Tar Yield}

The tar yield of the coal samples obtained (Table 1) showed that Shankodi had 31.95\% while Garin Maiganga, $17.2 \%$. This indicated that Shankodi coal yielded higher coal tar extract as compared to Garin Maiganga coal sample. However, the tar yield form these coals were greater than the results reported by [9].

\subsection{Chemical Composition of Coal Tar}

The GC-MS spectra of Garin Maiganga and Shankodi coal tar samples are shown in Figure 3 and Figure 4 respectively. According to the GC, combined with MS analysis, the qualitative and semi-quantities analyses of each peak appearing in the gaschromatogram can be determined. The weight percentage of every tar group (aliphatics, aromatics, ester and polar) present in Garin Maiganga sample are summarized in Table 2 while Shankodi in Table 3.

The main aliphatic compounds in coal tar were paraffin hydrocarbons while main components of aromatics group were mono aromatics, polycyclic aromatics hydrocarbons (PAHs), etc. PAHs mainly consist of naphthalene and its derivatives. The ester groups of coal tar contain mainly some oxygen compounds, such as acids and some small amount of aromatics compound containing N. The main components of polar groups in the coal tar are various phenyl ethanol, phenyl ester, etc.

Table 1. Comparison of coal tar properties with standard values.

\begin{tabular}{|c|c|c|c|}
\hline Properties & Garin Maiganga coal tar & Shankodi coal tar & ${ }^{*}$ Standard coal tar \\
\hline Appearance & Dark brown & Dark brown & Dark brown \\
\hline Odour & Aromatic odour & Aromatic odour & Aromatic odour \\
\hline Tar yield (wt\%) & 17.02 & 31.95 & - \\
\hline Viscosity $(\mathrm{cP})$ & 17.50 & 18.00 & $32-425$ \\
\hline Density $\left(\mathrm{g} / \mathrm{cm}^{3}\right)$ & 0.9156 & 0.9119 & $1.18-1.23$ \\
\hline $\mathrm{pH}$ & 6.55 & 6.50 & - \\
\hline Solubility & $\begin{array}{l}\text { Negligible in water, } \\
\text { mostly dissolves in } \\
\text { benzene, partially } \\
\text { dissolves in alcohols, } \\
\text { acetone, ether and } \\
\text { chloroform. }\end{array}$ & $\begin{array}{l}\text { Negligible in water, } \\
\text { mostly dissolves in } \\
\text { benzene, partially } \\
\text { dissolves in alcohols, } \\
\text { acetone, ether and } \\
\text { chloroform. }\end{array}$ & $\begin{array}{l}\text { Negligible in water, } \\
\text { mostly dissolves in } \\
\text { benzene, partially } \\
\text { dissolves in alcohols, } \\
\text { acetone, ether, } \\
\text { chloroform and } \\
\text { petroleum ether. }\end{array}$ \\
\hline
\end{tabular}

$*[18]$. 
Table 2. Major chemical composition of Garin Maiganga coal tar.

\begin{tabular}{ccc}
\hline Peak Number & Compounds & Percentage abundance (\%) \\
\hline 2 & 1,2,4-tri methyl benzene & 3.6 \\
6 & Phenyl ester & 8.91 \\
$3,6,12$ & Acids & 16.4 \\
9 & 2-methyl phenol & 8.82 \\
12 & Phenol-3-methyl-1-(2-methylphenyl) & 15.14 \\
14 & 1-nitro-ethyl-benzene & 7.06 \\
19 & 2,methyl naphthalene & 6.64 \\
22 & 2,6-dimethyl naphthalene & 6.14 \\
38 & 2-phenyl ethanol & 27.25 \\
\hline
\end{tabular}

Table 3. Major chemical composition of Shankodi coal tar.

\begin{tabular}{ccc}
\hline Peak Number & Composition & $\begin{array}{c}\text { Percentage } \\
\text { abundance (\%) }\end{array}$ \\
\hline 1 & 2-phenyl ethanol & 5.81 \\
2 & Methylene & 21.56 \\
3 & 1-ethyl-2-methyl benzene & 20.62 \\
7 & 1-methyl naphthalene & 14.33 \\
9 & 1,4-methyl naphthalene & 21.45 \\
13 & 1-Icosanol & 11.49 \\
25 & $1, \mathrm{H} 3 \mathrm{a}, 7$ methanoazulene,octahydro-3,6,8,8-tetramethyl & 4.74 \\
\hline
\end{tabular}

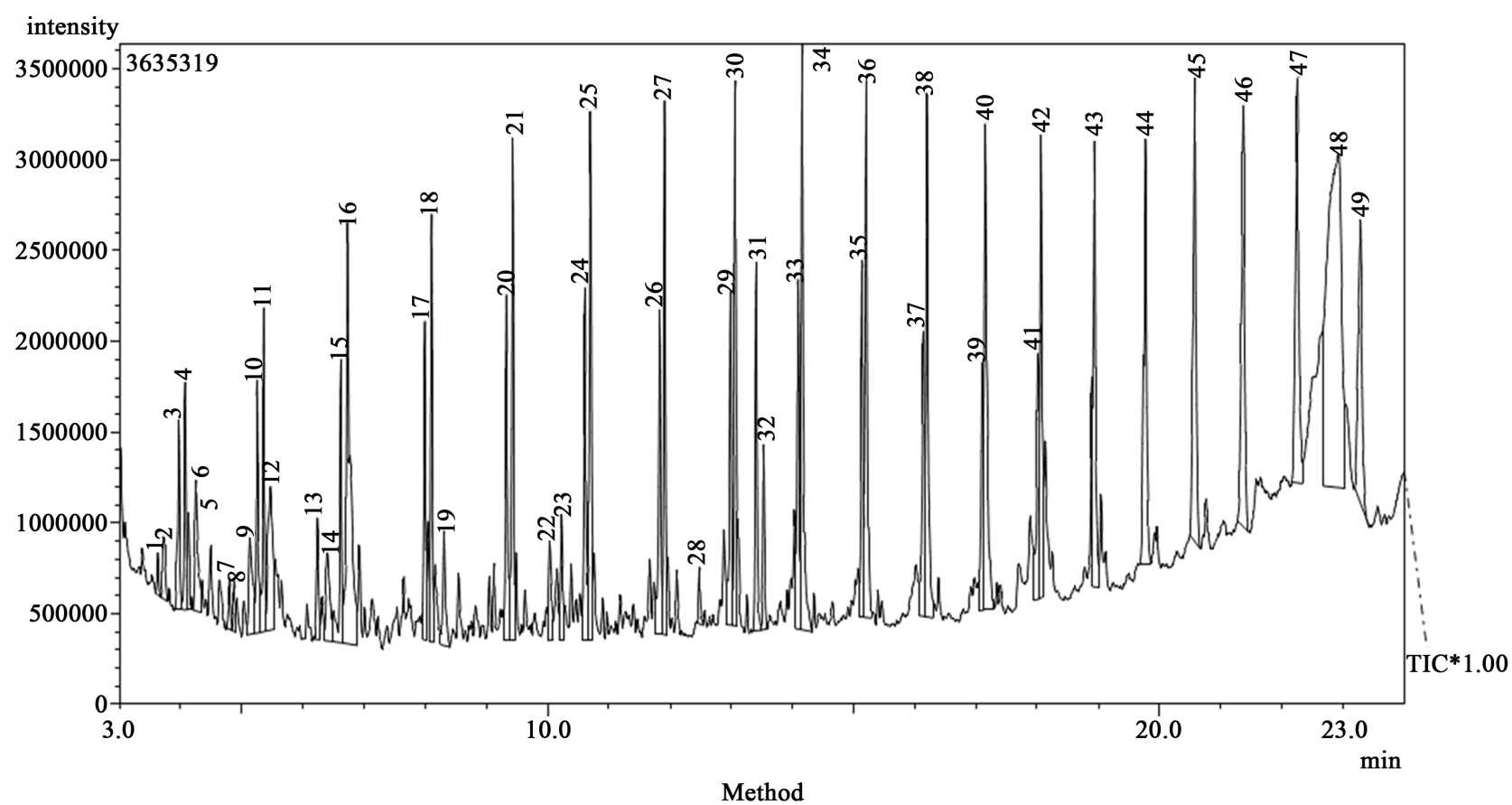

Figure 3. GC-MS spectra of Garin Maiganga coal tar. 


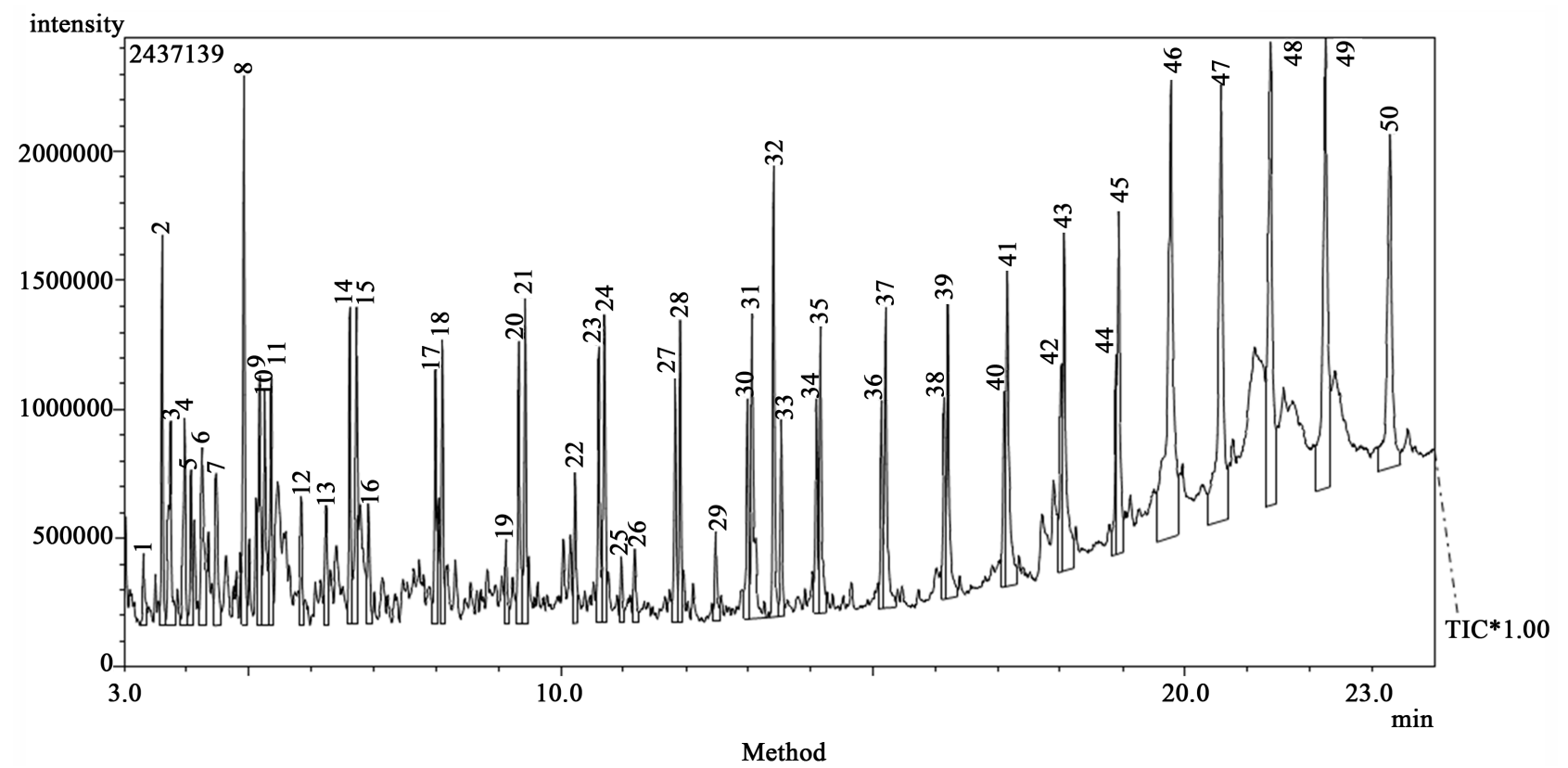

Figure 4. GC-MS spectra of Shankodi coal tar.

Garin Maiganga coal tar contains over 48 chemical compounds and from Table 2, 2-phenyl ethanol (benzene ethanol) is found in major abundance (27.25\%) followed by phenol-3-methyl-1-(2-methylpheyl) with abundance of $15.14 \%$. 2 methyl phenol (o-cresol), 1,2,4-tri methyl benzene (trimethyl benzene), 1-nitro-ethyl-benzene (phenyl ester), 2-methyl naphthalene and 2, 6-dimethyl naphthalene have abundance of $8.82 \%, 3.6 \%, 8.91 \%, 7.06 \%, 6.64 \%$ and $6.14 \%$ respectively. The chromatogram also identifies the presence of organic acids with abundance of $16.4 \%$ indicating that Garin Maiganga coal tar is acidic. They are mainly saturated fatty acid such as propionic and some compounds include methyl-nitro carbonate, 1,2-benzedicarboxylic acid, etc.

Shankodi coal tar contains less than 50 chemical compounds as shown in Figure 4. From Table 3, the major compound in Shankodi coal tar was methylene (compounds containing methylene group or bridge such as methylene cyclo-propene and methylene dichloride respectively) with abundance of $21.56 \%$ and followed by 1, 4-dimethylnapthalene with $21.45 \%$ while ethylmethyl benzene and 1-methyl naphthalene (methyl naphthalazine) were $20.62 \%$ and $14.33 \%$ respectively. Naphthalene compounds have abundance in Shankodi coal tar of over $20 \%$ and were greater than Garin Maiganga coal tar with less than $20 \%$. The increase of the chemical compounds down the Benue trough may be due to the geological formation of the coal deposits [19].

\subsection{Physicochemical Characteristics of Coal Tar Samples}

The $\mathrm{pH}$ of Garin Maiganga was 6.55 while Shankodi was 6.50 as shown in Table 1. The $\mathrm{pH}$ indicates that the coal tar samples were acidic. The acidity may be due to the presence of organic acids in the tar samples obtained by pyrolysis coal at low temperature [9]. 
The density of Garin Maiganga $\left(0.9156 \mathrm{~g} / \mathrm{cm}^{3}\right)$ is similar to Shankodi $(0.9119$ $\mathrm{g} / \mathrm{cm}^{3}$ ). The density of the coal tar samples depicted in Table 1 , are relatively lower compared to standard values $\left(1.18-1.23 \mathrm{~cm}^{3}\right)$. The low density may be due to the nature, coal type and geological formation of coal deposits [4] [19] [20]. However, the density of the coal tar sample is in agreement with results the report by [2] that Nigerian coals are predominantly low rank sub-Bituminous. The viscosity of Shankodi $(18.0 \mathrm{cP})$ is slightly higher than Garin Maiganga (17.5 cP) as shown in Table 1. This indicates that Garin Maiganga coal tar will flow more easily without resistance as compared to Shankodi. Generally, the viscosity values of these samples are lower than the standard ranged between 32 and 425 cP.

The refractive index of Garin Maiganga (0.6478) and Shankodi (0.6450) are similarly and this could be due to the both tar samples having the same colour (dark brown) as shown in Table 1.

The solubility test (Table 1 ) showed that Garin Maiganga and Shankodi samples were mostly soluble in benzene, partially soluble in ethanol, ether and chloroform while their solubility in water was negligible and is similar to standard coal tar.

\section{Conclusions}

Coal tar was successfully extracted from Garin Maiganga and Shankodi coals by fixed bed pyrolysis process. The percentage yield of Shankodi was $31.95 \mathrm{wt} \%$ while Garin Maiganga was $17.02 \mathrm{wt} \%$. The GC-MS revealed that the coal tar samples contain many chemical compounds ranging between 42 and 50 with benzo and naphthalene compounds occurring in all the samples. The physicochemical analysis also revealed that the samples are within the standard coal tar suggesting that the numerous chemical compounds obtained by pyrolysis can be separated for industrial applications.

\section{References}

[1] Jauro, A., Agho, M.O., Abaye, O.J., Obaje, N.G. and Abubakar, M.B.J. (2008) Petrographic Study of Coal in the Benue Trough. Mining Geology, 44, 11-18.

[2] Ryemshak, A.S. and Jauro, A. (2013) Proximate Analysis, Rheological Properties and Technological Applications of Some Nigerian Coals. International Journal of Industrial Chemistry, 1-7.

[3] Sori, R.M. (2008) Coking Properties of Chikila Coal (Grab Sample). Unpublished Seminar Paper Delivered at NMDC, Jos.

[4] Jauro, A. (2007) Characterization of Benue Trough Coal Extracts. PhD Thesis, Abubakar Tafawa Balewa Univeristy, Bauchi, Nigeria.

[5] Watt, M. (1996) The Chemical Structure of Coal Tar Char during Devolatilization. M.Sc. Thesis, Brigham Young University, Provo, Utah.

[6] Jiang, J., Qiyu, W., Yingyu, W., Weicheng, T. and Bo, X. (2006) GC/MS Analysis of Coal Tar Composition Produced from Coal Pyrolysis. Environmental Monitoring of China. 
[7] Babara, J.M., Peter, C., Van Metre, P.C., Jude, L.C., Alison, W.W., Mateo, S. and Williams, S.E. (2012) Toxicological Profile for Wood Creosote, Coal Tar, Coal Tar Pitch and Coal Tar Pitch Volatiles. Journal of Environmental Science and Technology, 1-20.

[8] Heinz-Gerhard, F. (1963) The Challenge in Coal Tar Chemicals. Journal of American Chemical Society, 55, 32-43.

[9] Fardhyanti, D.S. and Damayanti, A. (2015) Analysis of Coal Tar Composition Produced from Sub-Bituminous Kalimantan Coal Tar. International Journal of Chemical, Molecular, Nuclear, Materials and Metallurgical Engineering, 9, 32-42.

[10] Peter, C., Van Metre, P.C. and Mahler, B.J. (2012) Contributions of PAHs from Coal Tar Pavement Seal Coat and Storm Water Pollutions. Journal Science of the Total Environment, 409, 334-344.

[11] Van Metre, P.C. and Mahler, B.J. (2010) Contributions of PAHs from Coal Tar Pavement Sealcoat and Other Sources to 40 US Lakes. Science of the Total Environment, 409, 334-344. https://doi.org/10.1016/j.scitotenv.2010.08.014

[12] World Commission on Environment and Development (1987) Coal and Sustainable Development. World Coal Summit, Johannesburg, South Africa, 16-33.

[13] Jeffrey J. (2010) Characterization of DNAPL Derived from MGP Facilities. Report, Mikelson Environmental Inc., Moses Lake, WA, 1-31.

[14] Sori, R.M. (2017) Extraction and Evaluation of Coal tar from Coals Obtained along the Benue Trough and Its Application in the Production of Shampoo. Unpublished MSc. Thesis, Modibbo Adama University of Technology, Yola.

[15] Adeleke, A.O., Makan, R.S. and Ibitoye, S.A. (2007) Grayking Assay Characterization of Nigerian Enugu and Polish Bellview Coals for Co-Carbonization. Journal of Applied Sciences, 7, 455-458. https://doi.org/10.3923/jas.2007.455.458

[16] Sharma, P.P. (1998) Cosmetic Formulation, Manufacturing, and Quality Control. 3rd Edition, Vandana Publications, Lucknow, 644-647.

[17] AOAC (2000) Official Methods of Analysis International. Horwitz, W., Ed., 17th Edition, Gaithersburg, 1-68.

[18] Koppers Product Identification (2008) Material Safety Sheet. Koppers Carbon Materials \& Chemicals Pty Ltd., Mayfield, NSW, 1-7.

[19] Obaje, N.G. (1997) Petrographic Evaluation of the Coking Potential of Cretaceous Lafia-Obi Coal Deposit in the Benue Trough of Nigeria. Mining Geology, 43, 103-176.

[20] Hambly, E.M. (1998) The Chemical Structure Coal Tar Char during Devolatilization. Thesis, Brigham Young University, Provo, Utah. 
Submit or recommend next manuscript to SCIRP and we will provide best service for you:

Accepting pre-submission inquiries through Email, Facebook, LinkedIn, Twitter, etc. A wide selection of journals (inclusive of 9 subjects, more than 200 journals)

Providing 24-hour high-quality service

User-friendly online submission system

Fair and swift peer-review system

Efficient typesetting and proofreading procedure

Display of the result of downloads and visits, as well as the number of cited articles Maximum dissemination of your research work

Submit your manuscript at: http://papersubmission.scirp.org/

Or contact jmmce@scirp.org 